AUTHOR'S ABSTRACT OF THIS PAPER ISSUEU

BY THE BIBLIOGRAPHIO SERVICE, AUGUST 7

\title{
ON THE PROCESS OF DISAPPEARANCE OF THE CONUS ARTERIOSUS IN TELEOSTS ${ }^{1}$
}

\author{
WILBUR C. SMITH
}

The Department of Anatomy, Tulane University of Louisiana

SIXTEEN FIGURES

Considerable difficulty has been encountered in the classification of fishes and their different genera, and especially in drawing a distinct line between the Ganoids and Teleosts.

Gegenbaur ('66) found in the Ganoids and in a limited number of Teleosts, intercalated between the ventricle of the heart and the truncus arteriosus, two segments clearly distinguishable from one another. Of these segments, the caudal is called the conus arteriosus or bulbus cordis, while the cranial is called the bulbus arteriosus.

The conus arteriosus is a well-marked muscular structure, furnished with numerous valves, and is one of the characteristics of the Elasmobranchs and Ganoids. Teleosts, with the exception of a very limited number, have no conus.

It was once thought that the rudimentary conus, or its total absence, with but one tier of valves, was characteristic of the Teleost heart. Stannius in his researches ('54) found that Albula vulpes possessed two tiers of valves instead of one. Likewise Senior ('07) found the same true of Megalops cyprinoides, Pterothrissus gissu, and Tarpon atlanticus. Amia calva has the shortest conus and a fewer number of valves than any other Ganoid. Some of the Teleosts seem to have descended from a stem somewhat akin to Amia, notably the herring group. Some of the families of this group, for instance, Albula vulpes, Pterothrissus gissu, Magalops cyprinoides, and Tarpon atlanticus have almost as large a conus as Amia itself, but with two rows

${ }^{1}$ Material used chiefly from the University and Bellevue Hospital Medical School collection. 
of valves instead of three. Other nearly related genera have a distinct conus with only one row of valves.

Boas ('80), in his diagram of the Teleost heart, shows the valves to arise from fibrous tissue. This is erroneous, since it has since been found that all conus valves of Teloosts have their bases attached to muscle with some muscle fibers probably extending into the cusps. Boas' diagram for the Teleost represents the condition found in both Teleosts and Ganoids.

Favaro ('10) states that, from the point of view of comparative anatomy and embryology, we are not obliged to recognize in the conus and bulbus arteriosus autonomous and distinct organs, such as are observed in single orders and species, but rather structures which in part correspond to one another. Thereby he contradicts Gegenbaur's statement that the conus and bulbus arteriosus are separate and distinct segments. However, when one considers that Favaro had in mind only the part derived from vascular endothelium and Gegenbaur that derived from splanchnic mesoderm, both are correct. The intima and media of the bulbus are derived from embryonic vascular endothelium and are homologous with the intima of the conus and general vascular apparatus. Gegenbaur said that the conus differed from the bulbus in that the greater part of its thickness consists of heart muscle. This is quite true.

Hoyer ('00) advanced the theory that in Teleosts the conus had disappeared by intussusception into the ventricle.

I have examined serial sections of the hearts of the following fishes: Etrumeus teres, Coilia nasus, Clupea harengus, Ctengraulis mysticetes, Engraulis mordax, Clupanodon coeruleus, Stolephorus compressus, Harengula macropthalma, Chanos chanos, Opisthonema thrissa, Pomolobus pseudoharengus, Dorosoma cepedianum, Clupanodon lacepede, Notopterus, Pantodon, Mormyrus caballus, Alepocephalus agassizii, Osteoglossum bicirrhosum, Mesopus pretiosus, Thymallus signifer, Salmo irideus, Clupea alosa, Oncorhynchus chouicha, Osmerus mordax, Bathylagus benedicti, Notemigonus chrysoleucus, Elops saurus, Chrosomus erythrogaster, Chirocentrus dorab, Tarpon atlanticus, Hiodon tergisus, Campostoma anomalum, Albula 
vulpes, Pterois volaus, Plotosus anguillaris, Cantherines sandwicheusis, Balistapus undulatus, Ostracion cornutum, Chaetodon aetifer, Chaetodon trifasciata, Heterotis niloticus, Ophiocephalus striatus, Hippocampus atterimus, Syngathus peleagicus Gastrotokens biaculeatus, Amia calva, Polyodon spathula, and Lepidosteus plastostomus.

The specimen of Heterotis niloticus and Osteoglossum bicirrhosum measured $40 \mathrm{~cm}$. in length. The others ranged from 6 to $20 \mathrm{~cm}$. The illustrations as here reproduced are not all of the same magnification. It was considered most convenient for comparison to employ any magnification necessary to distinctly show the conus, when present, and the attachment of its valves. The figures are arranged in the order of what seemed to be the progressive disappearance of the conus arteriosus as found in specimens here studied.

I take this opportunity to thank Professor Senior, of The University and Bellevue Hospital Medical College, for the privilege of using material in the collection of this institution, and I sincerely thank Professor Ruth, of the University of Manila, Professor Jordan, of Leland Stanford University, and Mr. Rathbun, of the United States National Museum, for their kindness in sending me a number of the specimens enumerated.

I find that the hearts of Tarpon atlanticus, Osteoglossum bicirrhosum, Ophiocephalus striatus, Chaetodon aetifer, Coilia nasus, Chanos chanos, Albula vulpes, Notopterus, Plotosus anguillaris, Dorosoma cepedianum, and Heterotis niloticus, all show a distinct muscular conus. Figure 1 illustrates such a conus in Dorosoma cepedianum and figure 2 the similar condition in Heterotis niloticus. It was deemed unnecessary to submit illustrations of the remaining specimens mentioned since the conus in them was of similar appearance and structure.

The hearts of Balistapus undulatus, Pterois volaus, Stolophorus compressus, Pomolobus pseudoharengus, Elops saurus, Clupanodon coeruleus, Harengula macrothalma, Opisthonema thrissa, Engraulis mordax, Alepocephalus agassizii, and Ctengraulis mysticetes show a rudimentary conus of elastic tissue including a small amount of scattered cardiac muscle. These are shown in figures $3,4,5,6,7$, and 8 , respectively. 

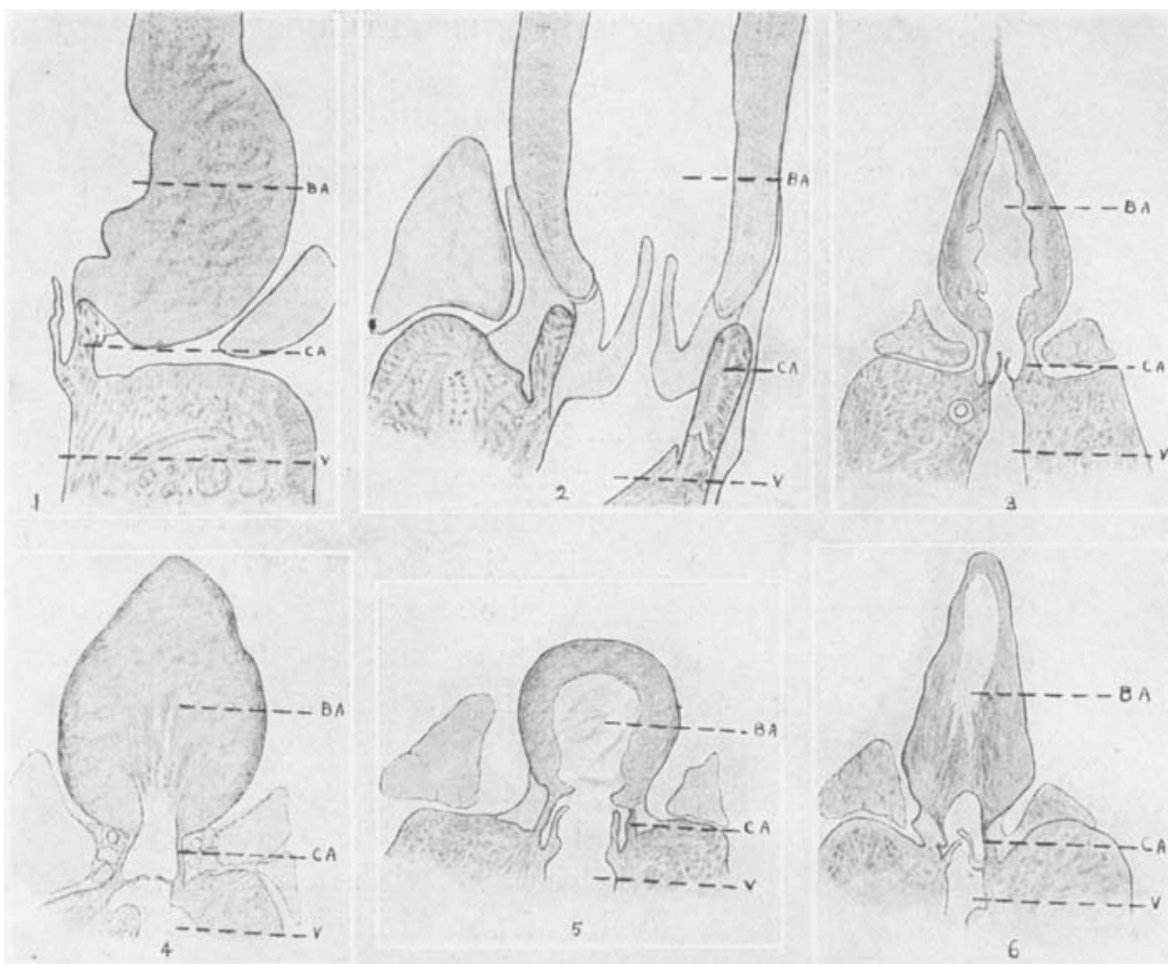

5

6
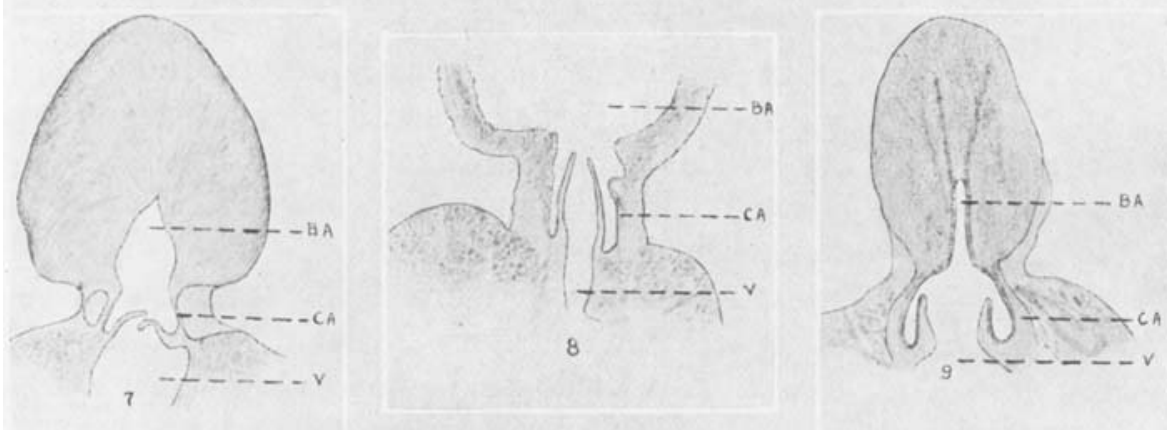

EXPLANATION OF THE FIGURES

The figures are all drawn to include only the cephalic ends of the hearts of the specimens named. The sections from which the drawings were made were selected from serial sections of the hearts and, as is evident, many of the sections pass obliquely through the cephalic ends. The figures represent hearts of specimens as follows:

1 Dorosoma cepedianum

3 Clupanodon coerlucus

2 Heterotis niloticus 4 Harengula macropthalma 


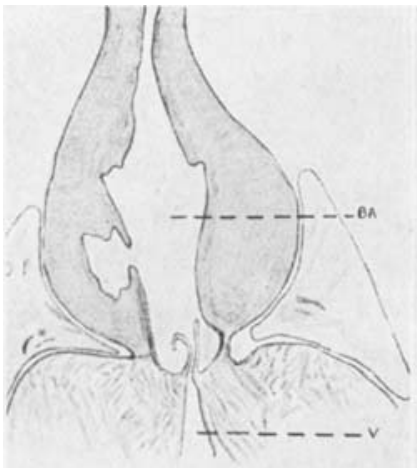

io

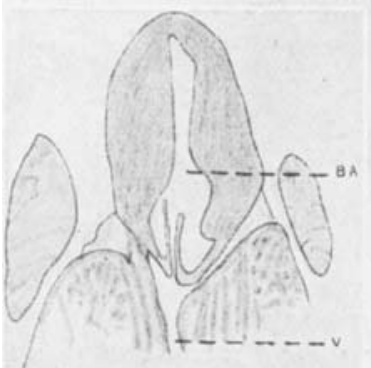

13

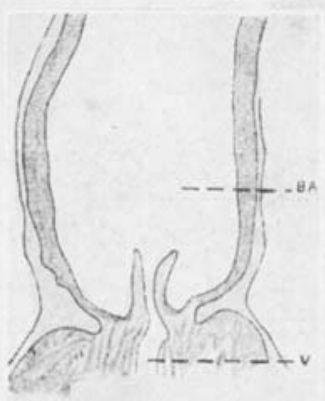

$1+$

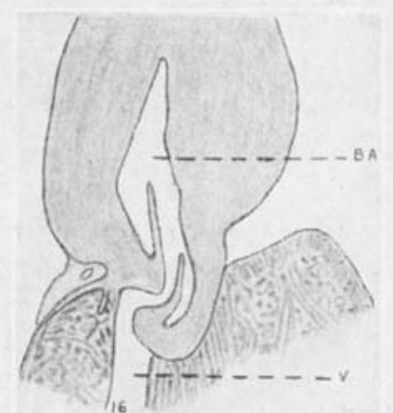

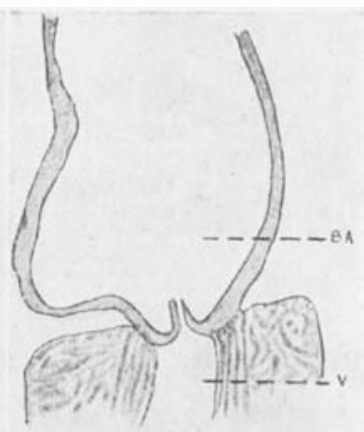

.12

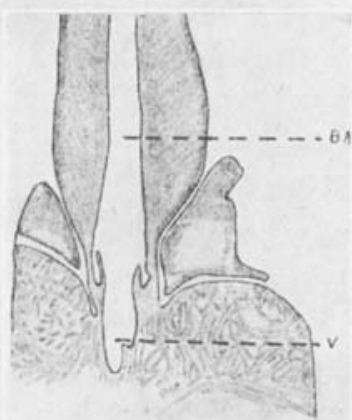

15
5 Ctengraulis mysticetes

6 Engraulis mordax

7 Opisthonema thrissa

8 Alepocephalus agassizii

9 Mormyrus caballus

10 Clupea harengus

B A, bulbus arteriosus
11 Bathylagus benedicti

12 Syngathus peleagicus

13 Hiodon tergisus

14 Hippocampus atterimus

15 Chirocentrus dorab

16 Pantodon

REFERENCE LETTERS

$\mathrm{CA}$, conus arteriosus. $\mathrm{V}$, ventricle 
In the remaining number of leleosts examined, the conus seems to have disappeared. The greater number of them appear to have lost it by intussusception (telescoping) into the ventricle. In figure 9, Mormyrus caballus, the valves are seen to be attached to intussuscepted conus muscle, caudal to the cephalic end of the heart, while on the other hand, in some that have lost their conus, one finds the conus valves not to be drawn into the ventricle, as in figure 9 but to be attached to its most cephalic ond, as in figure 10, Clupea harengus. In the hearts of Bathylagus benedicti, Syngathus peleagicus, and Hiodon tergisus, figures 11,12 , and 13 , respectively, the cusps are solely bulbar in their attachment and show no evidence of being drawn into the ventricle nor any direct structural relation with it. In Hippocampus atterimus and Chirocentrus dorab the valves are merely attached to the bulbus and to the aortic end of the ventricle with also no evidence of being drawn into the latter, while in the heart of Pantodon both cusps are attached to the caudal end of the bulbus, which, on the left side, is drawn into the ventricle.

I believe that Hoyer's statement that in Teleosts the conus has been lost by intussusception or recession into the ventricle applies to most species of Teleosts, but, on the other hand, it seems to me that in those hearts one should find the conus valves caudal to the aortic end of the heart, with their bases attached to the receded conus muscle. In the figures showing no conus and no drawing in of the valves, and in those showing the valves to have only bulbar attachment with no intussusception, it appears to me that in a limited number of Teleosts the conus is not intussuscepted into the ventricle, but is taken up by the caudal elongation of the bulbus.

The phenomenon of the disappearance of the conus arteriosus without intussusception of the valve cusps into the ventricle, as noted, may possibly be explained physiologically. One may consider that, on ventricular contraction when the blood is forced into the conus and bulbus, if during the succeeding contraction of the bulbus, the greater resistance offered to the passage of the blood through the branchial vessels necessitates a 
greater pressure and a hypertrophy of the bulbus, then there would result a stronger caudal regurgitation of the blood against the cusps of the conus valves. This caudal regurgitation might lead to a caudal compression and consequent obliteration of the conus.

I desire to express my appreciation to Professors H. D. Senior and Irving Hardesty for their aid and suggestions offered me in the preparation of this paper.

\section{LITERATURE CITED}

Boss, J. E. V. 1880 Über den Connus arteriosus bei Butirinus und bei andern Knochenfischen. Morph. Jahrb., Bd. 6, p. 527.

Favaro, G. 1911 Cono e bulbo Arteroso negli anamni. Monitore Zoologico Italiano, Anno. 22, p. 121.

Gegenbaur, C. 1866 Zur vergl. Anatomie des Herzens. Jenaische Zeitschrift, Bd. 2, p. 365 .

Hoyer, H. 1900 Bulletin international de l'académie des Sciences de Cracovie, no. 7 , p. 263.

Jordan and Everman Bulletin of the United States National Museum no. 47.

Mueller, J. $1846^{\circ}$ Über den Bau und die Grenzen der Ganoiden. Berlin, 1846.

Sentor, H. D. 1907 The conus arteriosus in Tarpon atlanticus. Biological Bulletin, vol. 12, no. 6 .

1907 Teleosts with a conus arteriosus having more than one row of valves. Anat. Rec., vol. 1, no. 4, pages 83-84.

1907 Note on the conus arteriosus of Megalops cyprinoides. Biological Bulletin, vol. 12, no. 6.

Stankius 1846 Bermerkungen über das Verhältnis der Ganoiden zu den Clupeiden, insbesondere zu Butirinus. Rostock, 1846. 